Indonesian Journal of Legality of Law
e-ISSN : 2477-197X
https://postgraduate.universitasbosowa.ac.id/

\title{
ANALISIS HUKUM TENTANG PENYANGKALAN TERDAKWA DI TINGKAT PERSIDANGAN DAN IMPLIKASINYA DALAM HUKUM PEMBUKTIAN
}

\author{
Legal Analysis Concerning the Denial of The Defendant's Statement at The Trial Level and Its Implication \\ in The Evidentiary Law
}

\author{
Idris $^{1}$, Ruslan Renggong ${ }^{2}$, Abdul Salam Siku ${ }^{2}$ \\ ${ }^{1}$ Sekolah Pendidikan Polisi Batua Makassar \\ ${ }^{1}$ Program Studi Ilmu Hukum Program Pascasarjana Universitas Bosowa \\ Email: spnidrtis@gmail.com
}

Diterima: 01 April 2020/Disetujui: 05 Juni 2020

\begin{abstract}
ABSTRAK
Penelitian ini bertujuan untuk menganalisis boleh-tidaknya terdakwa menyangkali keterangannya dalam persidangan. Dan untuk menganalisisnya bagaimana implikasi yuridis dari Penyangkalan terdakwa dalam hukum pembuktian, dengan metode penelitian yang digunakan adalah pendekatan normatif emperis. Penelitian ini menggunakan metode pendekatan normatif emperis. Di dalam penelitian hukum ini, penulis melakukan penelitian dengan mencari perkara-perkara pidana yang berkenaan dengan adanya penyangkalan keterangan terdakwa ditingkat persidangan Pengadilan (dalam hal ini di Pengadilan Negeri Makassar), kemudian menganalisa tentang sejauh manakah suatu peraturan atau perundang - undangan atau hukum yang sedang berlaku secara efektif mengenai penyangkalan keterangan terdakwa ditingkat persidangan dan implikasinya dalam pembuktian Hasil penelitian menunjukkan bahwa Penyangkalan terdakwa dalam persidangan boleh dilakukan oleh terdakwa, dengan syarat pencabutan dilakukan selama pemeriksaan persidangan pengadilan berlangsung dan harus disertai dengan alasan yang mendasar dan logis. Alasan yang mendasar dan logis tersebut mengandung arti bahwa alasan yang menjadi dasar pencabutan tersebut harus dapat dibuktikan kebenarannya dan diperkuat atau didukung oleh bukti-bukti lain yang menunjukkan bahwa alasan pencabutan tersebut benar dan dapat dibuktikan oleh hakim.
\end{abstract}

Kata Kunci: Hukum, Persidangan, Hukum Pembuktian

\section{ABSTRACT}

The study aims to analyze whether or not the defendant denying his statements in the trial. Also, it aims to analyze how the juridical implications of the denial of the defendant in the evidentaiary law with a reasearch method used is a normative emprical approach. The results showed that the defendant's denial in the trial may be conducted by the defendant, on the conditon of revocation conducted during court procedings and hearings must be accompanied by basic and logical reasons. The fundamental and logical reasons mean that the reasons are the basis for revocation must be proven true and strengthened or suuported by other evidence that shows that the reason for the revocation is true and can be proven by the judge.

Keywords: Law, Hearing, Evidence Law

\section{PENDAHULUAN}

Negara Indonesia adalah Negara yang berdasarkan atas hukum (rechtsstaat), tidak berdasarkan atas kekuasaan belaka (machtsstaat). Pernyataan tersebut secara tegas tercantum dalam Penjelasan Umum Undang-Undang Dasar 1945. Hal ini menunjukkan bahwa Indonesia adalah Negara hukum. Sebagai Negara hukum, Indonesia menerima hukum sebagai ideologi untuk menciptakan ketertiban, keamanan, keadilan serta kesejahteraan bagi warga negaranya. Konsekuensi dari itu semua adalah bahwa hukum mengikat setiap tindakan yang dilakukan oleh warga negara Indonesia.

Hukum bisa dilihat sebagai perlengkapan masyarakat untuk menciptakan ketertiban dan keteraturan dalam kehidupan masyarakat. Oleh karena itu hukum bekerja dengan cara memberikan petunjuk tentang tingkah laku dan karena itu pula hukum berupa norma (Satjipto Rahardjo, 1982: 14). Hukum yang berupa norma dikenal dengan sebutan norma hukum, dimana hukum mengikatkan diri pada masyarakat sebagai tempat bekerjanya hukum tersebut.

Untuk mewujudkan tujuan peradilan pidana dalam hal memutuskan seseorang bersalah atau tidak, peradilan pidana dengan prosedur yang diikat oleh aturan-aturan ketat tentang pembuktian yang mencakup semua batas-batas konstitusional dan berakhir pada pemeriksaan di pengadilan. Proses pemeriksaan perkara pidana yang tertuang dalam KUHAP, telah mencerminkan nilai-nilai yang tertuang dalan Due 
process model, sebab model ini menawarkan prosudural yang ketat, yang didukung oleh sikap batin penegak hukum untuk menghormati hak-hak warganya (Ruslan Renggong, 2014: 169)

Pembuktian memegang peranan yang sangat penting dalam proses pemeriksaan sidang pengadilan, karena dengan pembuktian inilah nasib terdakwa ditentukan, dan hanya dengan pembuktian suatu perbuatan pidana dapat dijatuhi hukuman pidana. Sehingga apabila hasil pembuktian dengan alat-alat bukti yang ditentukan undang-undang tidak cukup membuktikan kesalahan yang didakwakan kepada terdakwa, maka terdakwa dibebaskan dari hukuman, dan sebaliknya jika kesalahan terdakwa dapat dibuktikan, maka terdakwa harus dinyatakan bersalah dan kepadanya akan dijatuhkan pidana.

Pembuktian juga merupakan titik sentral hukum acara pidana. Hal ini dapat dibuktikan sejak awal dimulainya tindakan penyelidikan, penyidikan, prapenuntutan, pemeriksaan tambahan, penuntutan, pemeriksaan di sidang pengadilan, putusan hakim bahkan sampai upaya hukum, masalah pembuktian merupakan pokok bahasan dan tinjauan semua pihak dan pejabat yang bersangkutan pada semua tingkat pemeriksaan dalam proses peradilan, terutama bagi hakim. Oleh karena itu hakim harus hati-hati, cermat, dan matang dalam menilai dan mempertimbangkan nilai pembuktian serta dapat meneliti sampai dimana batas minimum kekuatan pembuktian atau bewijskracht dari setiap alat bukti yang sah menurut undang-undang.

Menurut Pasal 189 ayat (1) KUHAP, Keterangan terdakwa adalah apa yang terdakwa nyatakan di sidang tentang perbuatan yang dilakukan atau yang ia ketahui sendiri atau ia alami sendiri. Mengingat bahwa keterangan terdakwa yang memuat informasi tentang kejadian peristiwa pidana bersumber dari terdakwa, maka hakim dalam melakukan penilaian terhadap isi keterangan terdakwa haruslah cermat dan sadar bahwa ada kemungkinan terjadinya kebohongan atau keterangan palsu yang dibuat oleh terdakwa mengenai hal ikhwal kejadian atau peristiwa pidana yang terjadi.

Menurut Martiman Prodjohamidjojo (2003: 137), terhadap keterangan di muka penyidik dan keterangan dalam persidangan harus dibedakan, keterangan yang diberikan di muka penyidik disebut keterangan tersangka, sedangkan keterangan yang diberikan dalam persidangan disebut keterangan terdakwa. Dengan adanya perbedaan ini, penulis menilai akan memperjelas dari kedudukan masing-masing keterangan dalam pembuktian.

Adapun alasan yang kerap dijadikan dasar penyangkalan adalah bahwa pada saat memberikan keterangan di hadapan penyidik, terdakwa dipaksa atau diancam dengan kekerasan baik fisik maupun psikis untuk mengakui tindak pidana yang disangkakan kepadanya. Begitulah selalu alasan yang yang melandasi setiap Penyangkalan pengakuan yang dijumpai di sidang pengadilan.

Ditinjau dari segi yuridis, pencabutan ini sebenarnya dibolehkan dengan syarat pencabutan dilakukan selama pemeriksaan persidangan pengadilan berlangsung dan disertai alasan yang mendasar dan logis (M. Yahya Harahap, 2016: 325). Sepintas terkesan bahwa syarat pencabutan tersebut mudah dipahami dan mudah untuk dilakukan sehingga diperkirakan penerapannya pun akan lancar tanpa permasalahan. Akan tetapi, pada kenyataannya tidaklah demikian karena ternyata dalam praktek di persidangan pencabutan begitu banyak menimbulkan permasalahan.
Terutama mengenai penilaian hakim terhadap alasan Penyangkalan terdakwa, dimana dalam praktek di persidangan hakim tidaklah mudah menerima alasan Penyangkalan terdakwa.

Permasalahan lain terkait dari Penyangkalan terdakwa adalah mengenai eksistensi keterangan terdakwa yang diberikan di luar sidang (The Confession Outside the Court), dalam hal digunakan untuk membantu menemukan alat bukti dalam persidangan sebagaimana ketentuan Pasal 189 ayat (2) KUHAP (iSebab sesuatu hal yang fungsi dan nilainya digunakan untuk membantu mempertegas alat bukti yang sah, maka kedudukannya pun telah berubah menjadi alat bukti, termasuk pengakuan terdakwa pada tingkat penyidikan (M. Yahya Harahap, 2016: 323).

Masalah Penyangkalan terdakwa ini juga akan membawa permasalahan lain, yaitu persoalan berkaitan dengan implikasi pencabutan tersebut terhadap kekuatan hukum pembuktian, serta pengaruhnya terhadap alat bukti lain yang sah menurut undang-undang.

Tujuan dari penelitian ini adalah mendeskripsikan apakah terdakwa diperkenankan untuk mencabut keterangannya dalam persidangan dan bagaimana implikasi hukum dari Penyangkalan terdakwa dalam hukum pembuktian.

\section{METODE}

Metode penelitian yang digunakan adalah pendekatan normatif emperis. Di dalam penelitian hukum ini, penelitian dengan mencari perkara-perkara pidana yang berkenaan dengan adanya penyangkalan keterangan terdakwa ditingkat persidangan Pengadilan (dalam hal ini di Pengadilan Negeri Makassar), kemudian menganalisa tentang sejauh manakah suatu peraturan atau perundang-undangan atau hukum yang sedang berlaku secara efektif mengenai penyangkalan keterangan terdakwa ditingkat persidangan dan implikasinyadalam hukum pembuktian.

Ruang lingkup Pada pembahasan ini terfokus pada:

a) Penyangkalan terdakwa dalam persidangan dalam perkara pidana yang disidangkan di pengadilan Negeri Makassar (Putusan pengadilan Negeri Makassar Nomor: 179 / Pid. Sus / 2017 / Pn. Mks, tanggal 11 April 2017).

b) Peran Hakim dalam memutus perkara pidana dan impliksainya dalam hukum pembuktian.

Lokasi penelitian di Kantor Pengadilan Negeri Makassar berada di jalan R.A. Kartini Nomor 18/23, Kelurahan Baru, Kecamatan Ujung Pandang Kota Makassar, Provisnsi Sulawesi Selatan dan berada pada titik koordinat $119^{0} 24^{1} \mathrm{BT}$ 508'90,7" LS.

Metode pengumpulan data yang di gunakan adalah dengan mempelajari hukum primer dan bahan hukum sekunder baik yang berupa peraturan dan norma hukum pidana, buku-buku, makalah, jurnal artikel internet, dan penulis melakukan tanya jawab (wawancara) dengan Narasumber Dodi Indrasakti (Hakim Pengadilan Negeri Makassar pada tanggal 21 November 2019) untuk memperoleh informasi yang diinginkan.

Pada penelitian hukum normatif, pengolahan data dilakukan dengan cara mensistematika terhadap bahan-bahan 
hukum tertulis. Sistematisasi berarati membuat klasifikasi terhadap bahan-bahan hukum tersebut untuk

\section{HASIL DAN PEMBAHASAN}

\subsection{Tinjauan Umum Tentang Pembuktian}

a) Pengertian Pembuktian

KUHAP tidak memberikan penjelasan mengenai pengertian pembuktian, KUHAP hanya memuat jenis-jenis alat bukti yang sah menurut hukum, yang tertuang dalam Pasal 184 ayat (1) KUHAP. Subekti (2001: 1) menerangkan bahwa "Membuktikan ialah meyakinkan hakim tentang kebenaran dalil atau dalil-dalil yang dikemukakan dalam suatu sengketa"

Martiman Prodjohamidjojo (2003 11) mengemukakan membuktikan mengandung maksud dan usaha untuk menyatakan kebenaran atas sesuatu peristiwa, sehingga dapat diterima akal terhadap kebenaran peristiwa tersebut.

Pembuktian adalah ketentuan-ketentuan yang berisi penggarisan dan pedoman tentang cara-cara yang dibenarkan undang-undang membuktikan kesalahan yang didakwakan kepada terdakwa. Pembuktian juga merupakan ketentuan yang mengatur alat-alat bukti yang dibenarkan undang-undang dan boleh dipergunakan hakim membuktikan kesalahan yang didakwakan (M. Yahya Harahap, 2016: 273).

Hukum pembuktian adalah merupakan sebagian dari hukum acara pidana yang mengatur macam-macam alat bukti yang sah menurut hukum, sistem yang dianut dalam pembuktian, syarat-syarat dan tata cara mengajukan bukti tersebut serta kewenangan hakim untuk menerima, menolak dan menilai suatu pembuktian (Hari Sasangka dan Lily Rosita, 2003: 10).

Penuntut umum bertindak sebagai aparat yang diberi wewenang untuk mengajukan segala daya upaya membuktikan kesalahan yang didakwakannya kepada terdakwa. Sebaliknya terdakwa atau penasihat hukum mempunyai hak untuk melemahkan dan melumpuhkan pembuktian yang diajukan penuntut umum, sesuai dengan cara-cara yang dibenarkan undang-undang. Terutama bagi hakim, harus benar-benar sadar dan cermat menilai dan mempertimbangkan kekuatan pembuktian yang diketemukan selama pemeriksaan persidangan (M. Yahya Harahap, 2016: 274).

b) Prinsip-Prinsip Pembuktian

Prinsip-prinsip pembuktian antara lain:

1) Hal yang secara umum sudah diketahui tidak perlu dibuktikan.

Prinsip ini terdapat pada Pasal 184 ayat (2) KUHAP yang berbunyi: "Hal-hal yang secara umum sudah diketahui tidak perlu dibuktikan" atau disebut dengan istilah notoire feiten. Secara garis besar fakta notoir dibagi menjadi dua golongan,yaitu: a) sesuatu atau peristiwa yang diketahui umum bahwa sesuatu atau peristiwa tersebut memang sudah demikian halnya atau semestinya demikian, b) sesuatu kenyataan atau pengalaman yang selamanya dan selalu mengakibatkan demikian atau selalu merupakan kesimpulan demikian.

2) Menjadi saksi adalah kewajiban.

Kewajiban seseorang menjadi saksi diatur pada penjelasan Pasal 159 ayat (2) KUHAP yang menyebutkan: "Orang yang menjadi saksi setelah dipanggil ke suatu sidang pengadilan untuk memberikan keterangan tetapi dengan menolak kewajiban itu ia dapat dikenakan pidana berdasarkan ketentuan undangundang yang berlaku. Demikian pula dengan ahli."

3). Satu saksi bukan saksi (unus testis nullus testis)

Prinsip ini terdapat pada Pasal 185 ayat (2) KUHAP yang berbunyi: "Keterangan seorang saksi saja tidak cukup untuk membuktikan bahwa terdakwa bersalah terhadap perbuatan yang didakwakan kepadanya”.

Menurut KUHAP, keterangan satu saksi bukan saksi tidak berlaku bagi pemeriksaan cepat. Hal ini dapat disimpulkan dari penjelasan Pasal 184 KUHAP sebagai berikut: "Dalam acara pemeriksaan cepat, keyakinan hakim cukup didukung satu alat bukti yang sah". Jadi, ini berarti satu saksi, satu keterangan ahli, satu surat, satu petunjuk, atau keterangan terdakwa disertai keyakinan hakim cukup sebagai alat bukti untuk memidana terdakwa dalam perkara cepat (M. Yahya Harahap, 2016: 267).

4) Pengakuan terdakwa tidak menghapuskan kewajiban penuntut umum membuktikan kesalahan terdakwa

Prinsip ini merupakan penegasan dari lawan prinsip "pembuktian terbalik" yang tidak dikenal oleh hukum acara pidana yang berlaku di Indonesia. Menurut Pasal 189 ayat (4) KUHAP yang berbunyi: "Keterangan terdakwa saja tidak cukup untuk membuktikan bahwa ia bersalah melakukan perbuatan yang didakwakan kepadanya, melainkan harus disertai dengan alat bukti lain".

5) Keterangan terdakwa hanya mengikat pada dirinya sendiri.

Prinsip ini diatur pada Pasal 189 ayat (3) KUHAP yaitu: "Keterangan terdakwa hanya dapat digunakan terhadap dirinya sendiri". Ini berarti apa yang diterangkan terdakwa di sidang pengadilan hanya boleh diterima dan diakui sebagai alat bukti yang berlaku dan mengikat bagi diri terdakwa sendiri (Adnan Paslyadja, 2009: 8-15).

Menurut asas ini, apa yang diterangkan seseorang dalam persidangan yang berkedudukan sebagai terdakwa, hanya dapat dipergunakan sebagai alat bukti terhadap dirinya sendiri. Jika dalam suatu perkara terdakwa terdiri dari beberapa orang, masing-masing keterangan setiap terdakwa hanya merupakan alat bukti yang mengikat kepada dirinya sendiri. Keterangan terdakwa A tidak dapat dipergunakan terhadap terdakwa B, demikian sebaliknya (M. Yahya Harahap, 2016: 321).

c) Teori-Teori atau Sistem Pembuktian

Sebelum meninjau sistem pembuktian yang dianut oleh KUHAP, ada baiknya ditinjau beberapa ajaran yang berhubungan dengan sistem pembuktian. Gunanya sebagai perbandingan dalam memahami sistem pembuktian yang diatur dalam KUHAP.

Adapun teori sistem pembuktian adalah sebagai berikut:

1). Sistem Atau Teori Pembuktian Berdasarkan Keyakinan Hakim Semata (Conviction In Time)

Menurut M. Yahya Harahap (2016) bahwa sistem pembuktian Convention in time menentukan salah tidaknya seorang terdakwa, semata - mata ditentukan oleh penilaian "keyakinan" hakim. Keyakinan hakim yang menentukan keterbuktian kesalahan terdakwa. Dari mana hakim menarik dan menyimpulkan kayakinannya, tidak menjadi dalam sistem ini. Keyakinan boleh diambil dan disimpulkan hakim dari alat - alat bukti yang 
diperiksanya dalam sidang pengadilan dan bisa juga hasil pemeriksaan alat - alat bukti itu di abaikan hakim dan langsung menarik keyakinan dari keterangan dan pengakuan terdakwa.

Sistem pembuktian conviction in time berarti keyakinan semata. Artinya dalam menjatuhkan putusan, dasar pembuktiannya semata - mata diserahkan kepada keyakinan hakim. Dia tidak terikat kepada bukti, namun atas dasar keyakinan yang timbul dari hati nurani dan sifat bijaksana seorang hakim, ia dapat menjatuhkan putusan (Eddy O.S Hiariej,2012)

2) Sistem Atau Teori Pembuktian Berdasar Keyakinan Hakim Atas Alasan Yang Logis (Conviction In Raisone)

Keyakinan hakim dalam sistem pembuktian convition in raisone harus dilandasi oleh "reasoning" atau alasan-alasan. Dan reasoning itu sendiri harus pula "reasonable" yakni berdasarkan alasan-alasan yang dapat diterima oleh akal dan nalar, tidak semata-mata berdasarkan keyakinan yang tanpa batas. Sistem pembuktian ini sering disebut dengan sistem pembuktian bebas.

Dalam konteks hukum acara pidana di Indonesia, Conviction raisonee digunakan dalam persidangan tindak pidana ringan, termasuk perkara lalu lintas dan persidangan perkara pidana dalam acara cepat yang tidak membutuhkan jaksa penuntut umum untuk menghadirkan terdakwa, tetapi polisi yang mendapatkan kuasa dari jaksa penuntut umum dapat menghadirkan terdakwa dalam sidang pengadilan. (Eddy O.S. Hiariej, 2012: 17).

3) Sistem Atau Teori Pembuktian Menurut Undang-Undang Secara Positif (Positief Wettelijk Bewijstheorie)

Sistem ini ditempatkan berhadap-hadapan dengan sistem pembuktian conviction in time, karena sistem ini menganut ajaran bahwa bersalah tidaknya terdakwa didasarkan kepada ada tiadanya alat-alat bukti sah menurut undang-undang yang dapat dipakai membuktikan kesalahan terdakwa.

Menurut Eddy O.S. Hiariej (2012: 15 ) yang menyatakan bahwa dalam teori Positief Wetteleijk bewijstheorie, hakim terikat secara positif kepada alat bukti menurut undang - undang. Artinya jika dalam pertimbangan, hakim telah menganggap terbukti suatu perbuatan sesuai dengan alat - alat bukti yang disebut dalam undang - undang tanpa diperlukan keyakinan, hakim dapat menjatuhkan putusan.

4) Sistem Atau Teori Pembuktian Menurut Undang-undang Secara Negatif (Negatief Wettelijk Stelsel)

Sistem pembuktian negatief wettelijk terletak antara dua sistem yang berhadap-hadapan, yaitu antara sistem pembuktian positif wettelijk dan sistem pembuktian conviction intime. Artinya hakim hanya boleh menyatakan terdakwa bersalah melakukan tindak pidana yang didakwakan apabila ia yakin dan keyakinannya tersebut didasarkan kepada alat-alat bukti yang sah menurut undang-undang dan dalam sistem negatif wetteljik ada dua hal yang merupakan syarat untuk membuktikan kesalahan terdakwa, yakni: pertama, Wettelijk yaitu adanya alat-alat bukti yang sah dan ditetapkan oleh undang-undang dan kedua, Negatif, yaitu adanya keyakinan (nurani) dari hakim, sehingga berdasarkan bukti-bukti tersebut hakim meyakini kesalahan terdakwa. Antara alat-alat bukti dengan keyakinan diharuskan adanya hubungan causal (sebab akibat).

Dasar pembuktian menurut keyakinan hakim yang timbul dari alat-alat bukti dalam undang-undang secara negatif. Secara tegas dasar pembuktian ini dinyatakan dalam pasal 183 KUHAP,"Hakim tidak boleh menjatuhkan pidana kepada seorang kecuali apabila dengan sekurang-kurangnya dua alat buktiyang sah ia memperoleh keyakinan bahwa suatu tindak pidana benar-benar terjadi dan bahwa terdakwalah yang bersalah melakukannya".(Eddy O.S. Hiariej (2012)

d) Alat-Alat Bukti Yang Sah Dalam Pembuktian Hukum Acara Pidana

Alat bukti adalah segala sesuatu yang ada hubungannya dengan suatu perbuatan, dimana dengan alat-alat bukti tersebut, dapat dipergunakan sebagai bahan pembuktian guna menimbulkan keyakinan hakim atas kebenaran adanya suatu tindak pidana yang telah dilakukan terdakwa (Hari Sasangka dan Lily Rosita, 2003).

Adapun alat-alat bukti yang sah menurut Pasal 184 ayat

(1) KUHAP, adalah:

1) Keterangan saksi

Menurut Pasal 1 butir 27 KUHAP, keterangan saksi adalah salah satu alat bukti dalam perkara pidana yang berupa keterangan dari saksi mengenai suatu peristiwa pidana yang ia dengar sendiri, ia lihat sendiri, dan ia alami sendiri dengan menyebut alasan dari pengetahuannya itu. Dalam pasal 185 ayat (5) KUHAP dinyatakan bahwa baik pendapat maupun rekaan, yang diperoleh dari hasil pemikiran saja, bukan merupakan keterangan dan menurut Pasal 185 ayat (1) KUHAP, memberi batasan pengertian keterangan saksi dalam kapasitasnya sebagai alat bukti, bahwa: "Keterangan saksi sebagai alat bukti ialah apa yang saksi nyatakan di siding pengadilan".

2) Keterangan ahli

Memperhatikan bunyi pasal 1 angka 28 KUHAP, dapat ditarik suatu pengertian bahwa : a) keterangan ahli ialah keterangan yang diberikan seorang ahli yang memilki "keahlian khusus" tentang masalah yang diperlukan penjelasannya dalam suatu perkara pidana yang sedang diperiksa, b) maksud keterangan khusus dari ahli, agar perkara pidana yang sedang diperiksa “ menjadi terang " demi untuk penyelesaian pemeriksaan perkara yang bersangkutan.

Menurut M. Yahya Harahap (2016; 295) "Perbedaan antara keterangan seorang saksi dengan seorang ahli, ialah bahwa keterangan seorang saksi mengenai hal-hal yang di alami oleh saksi itu sendiri (eigen waarneming), sedang keterangan seorang ahli ialah mengenai suatu penghargaan dari hal-hal yang sudah nyata ada dan pengambilan kesimpulan dari hal-hal itu."

Dalam Pasal 186 KUHAP menyatakan ahli ialah apa yang seorang ahli nyatakan disidang pengadilan. Meskipun tidak ada pengertian dan batasan yang jelas tentang apa yang dimaksud dengan keterangan ahli, namun KUHAP menetapkan keterangan ahli sebagai alat bukti yang sah. Bahkan ditempatkan pada urutan kedua sesudah alat bukti keterangan saksi. 
3) Surat

Menurut Pasal 187 ayat (1) huruf c KUHAP, dibuat atas sumpah jabatan atau dikuatkan dengan sumpah, adalah: a) berita acara dan surat lain dalam bentuk resmi yang dibuat oleh pejabat umum yang berwenang atau yang dibuat di hadapannya, yang memuat keterangan tentang kejadian atau keadaan yang didengar, dilihat atau yang dialaminya sendiri, disertai dengan alasan yang jelas dan tegas tentang keterangannya itu, b) surat yang dibuat menurut ketentuan peraturan perundang-undangan atau surat yang dibuat oleh pejabat mengenal hal yang termasuk dalam tata laksana yang menjadi tanggung jawabnya dan yang diperuntukkan bagi pembuktian sesuatu hal atau sesuatu keadaan, c) surat keterangan dari seorang ahli yang memuat pendapat berdasarkan keahliannya mengenai sesuatu hal atau sesuatu keadaan yang diminta secara resmi dan padanya, d) surat lain yang hanya dapat berlaku jika ada hubungannya dengan isi dari alat pembuktian yang lain.

4) Petunjuk

Menurut Pasal 188 ayat (1) KUHAP, Petunjuk adalah perbuatan, kejadian atau keadaan, yang karena persesuaiannya, baik antara yang satu dengan yang lain, maupun dengan tindak pidana itu sendiri, menandakan bahwa telah terjadi suatu tindak pidana dan siapa pelakunya.

5) Keterangan terdakwa

Menurut Pasal 189 ayat (1) KUHAP, Keterangan terdakwa adalah apa yang terdakwa nyatakan di sidang tentang perbuatan yang dilakukan atau yang ia ketahui sendiri atau ia alami sendiri.

e) Beban Pembuktian dan Tingkat Keterbuktian

Hukum pembuktian harus menentukan dengan tegas kepundak siapa beban pembuktian (burden of proof, burden of producing evidence) harus diletakkan. Hal ini karena dipundak siapa beban pembuktian diletakkan oleh hukum, akan menentukan secara langsung bagaimana akhir dari suatu proses hukum dipengadilan.

Menurut Fuady (2006) bahwa yang dimaksud dengan beban pembuktian adalah suatu penentuan oleh hukum tentang siapa yang harus membuktikan suatu fakta yang dipersoalkan di pengadilan, untuk membuktikan dan meyakinkan pihak manapun bahwa fakta tersebut memang benar - benar terjadi sperti yang diungkapkannya, dengan konsekuensi hukum bahwa jika tidak dapat dibuktikan oleh pihak yang dibebani pembuktian, fakta tersebut dianggap tidak pernah terjadi seperti yang diungkapkan oleh pihak yang mengajukan fakta tersebut dipengadilan.

Oleh karena itu dalam hukum pidana disebutkan bahwa tingkat pembuktiannya harus lebih tinggi dan lebih meyakinkan. Sesuai dengan pasal 183 KUHAP bahwa pembuktian dalam hukum acara pidana haruslah sampai pada tingkat "terbukti dengan meyakinkan ".

\subsection{Tinjauan Umum Tentang Alat Bukti Keterangan Terdakwa}

a) Dasar Hukum Alat Bukti Keterangan Terdakwa.

1) Keterangan terdakwa (Pasal 184 huruf e dan Pasal 189 KUHAP)

Dalam pasal 189 KUHAP :1) keterangan terdakwa ialah apa yang terdakwa nyatakan disidang pengadilan tentang perbuatan yang ia lakukan atau yang ia ketahui sendiri atau alami sendiri, 2).keterangan terdakwa yang diberikan diluar sidang dapat digunakan untuk membantu menemukan bukti disidang, asalkan keterangan itu didukung oleh suatu alat bukti yang sah sepanjang mengenai hal yang didakwakan kepadanya, 3). keterangan terdakwa hanya dapat digunakan terhadap dirinya sendiri, 4). keterangan terdakwa saja tidak cukup untuk membuktikan bahwa ia bersalah melakukan perbuatan yang didakwakan kepadanya, melainkan harus disertai dengan alat bukti yang lain.

2) Pemeriksaan terdakwa (Pasal 175 sampai Pasal 178 KUHAP),

Pasal 175 KUHAP: "Jika terdakwa mau menjawab atau menolak untuk menjelaskan pertanyaan yang diajukan kepadanya, hakim ketua sidang menganjurkan untuk menjawab dan setelah itu pemeriksaan dilanjutkan"

Pasal 176 KUHAP :1) jika terdakwa bertingkah laku yang tidak patut sehingga mengganggu ketertiban sidang, hakim ketua sidang menegurnya dan jika teguran itu tidak diindahkan ia memerintahkan supaya terdakwa dikeluarkan dari ruang sidang, kemudian pemeriksaan perkara pada waktu itu dilanjutkan tanpa hadirnya terdakw, 2)Dalam hal terdakwa secara terus menerus bertingkah laku tidak yang patut sehingga mengganggu ketertiban sidang, hakim ketua sidang mengusahakan upaya sedemikian rupa sehingga putusan tetap dijatuhkan dengan hadirnya terdakwa

b) Pengertian Terdakwa dan Tersangka.

Menurut Pasal 1 butir 15 KUHAP terdakwa adalah " seorang dituntut, diperiksa dan diadili di sidang pengadilan”. Terdakwa adalah orang yang karena perbuatan atau keadaannya berdasarkan alat bukti minimal didakwa melakukan tindak pidana kemudian dituntut, diperiksa dan diadili di sidang pengadilan (Adnan Paslyadja, 2009: 69).

Sedangkan tersangka sendiri menurut Pasal 1 butir 14 KUHAP adalah "seorang yang karena perbuatannya atau keadaannya, berdasarkan bukti permulaan patut diduga sebagai pelaku tindak pidana”.

c) Pengertian Alat Bukti Keterangan Terdakwa

Alat bukti keterangan terdakwa diatur secara tegas oleh Pasal 189 KUHAP, sebagai berikut: a) keterangan terdakwa adalah apa yang terdakwa nyatakan di sidang tentang perbuatan yang dilakukan atau yang ia ketahui sendiri atau ia alami sendir, b) keterangan terdakwa yang diberikan di luar sidang dapat digunakan untuk membantu menemukan bukti di sidang asalkan keterangan itu didukung oleh suatu alat bukti yang sah sepanjang mengenai hal yang didakwakan kepadanya, c) keterangan terdakwa hanya dapat digunakan terhadap dirinya sendiri, d) keterangan terdakwa saja tidak cukup untuk membuktikan bahwa ia bersalah melakukan perbuatan yang didakwakan kepadanya, melainkan harus disertai dengan alat bukti yang lain.

Menurut Pasal 189 ayat (1) KUHAP, keterangan terdakwa ialah apa yang terdakwa nyatakan di sidang pengadilan tentang perbuatan yang ia lakukan atau ia ketahui sendiri atau alami sendiri. Sehingga secara garis besar keterangan terdakwa adalah: a) apa yang terdakwa "nyatakan" atau "jelaskan" di sidang pengadilan, b) dan apa yang dinyatakan atau dijelaskan itu ialah tentang perbuatan yang terdakwa lakukan atau mengenai yang ia ketahui atau yang berhubungan dengan apa yang terdakwa alami sendiri dalam peristiwa pidana yang sedang diperiksa (M. Yahya Harahap, 2016: 319) 


\section{d) Asas Penilaian Keterangan Terdakwa}

Sudah barang tentu tidak semua keterangan terdakwa dinilai sebagai alat bukti yang sah. Sehingga untuk menentukan sejauh mana keterangan terdakwa dapat dinilai sebagai alat bukti yang sah menurut undang-undang, diperlukan beberapa asas sebagai landasan berpijak, antara lain: a) keterangan itu dinyatakan di sidang pengadilan, b) keterangan yang diberikan di persidangan. Pernyataan terdakwa meliputi tentang perbuatan yang terdakwa lakukan sendiri, terdakwa sendirilah yang melakukan perbuatan itu, dan bukan orang lain selain terdakwa, tentang apa yang diketahui sendiri oleh terdakwa dan keterangan terdakwa hanya merupakan alat bukti terhadap dirinya sendiri.

Menurut asas ini, apa yang diterangkan seseorang dalam persidangan dalam kedudukannya sebagai terdakwa, hanya dapat dipergunakan sebagai alat bukti terhadap dirinya sendiri. Jika dalam suatu perkara terdakwa terdiri dari beberapa orang, masing-masing keterangan terdakwa hanya mengikat kepada dirinya sendiri. Dengan kata lain keterangan terdakwa yang satu tidak boleh dijadikan alat bukti bagi terdakwa lainnya (M. Yahya Harahap, 2003 : 320-321).

e) Keterangan Terdakwa Saja Tidak Cukup Membuktikan Kesalahannya

Asas ini ditegaskan dalam Pasal 189 ayat (4) yaitu: "Keterangan terdakwa saja tidak cukup untuk membuktikan bahwa ia bersalah melakukan perbuatan yang didakwakan kepadanya melainkan harus disertai dengan alat bukti yang lain".

Pada hakikatnya asas ini hanya merupakan penegasan kembali prinsip batas minimum pembuktian yang diatur dalam Pasal 183 KUHAP. Pasal 183 KUHAP telah menentukan asas pembuktian bahwa untuk menjatuhkan hukuman pidana terhadap seorang terdakwa, kesalahannya harus dapat dibuktikan; "dengan sekurang-kurangnya dua alat bukti yang sah" (M. Yahya Harahap, 2003: 322).

f) Keterangan Terdakwa di Luar Sidang (The Confession Outside the Court)

Salah satu asas penilaian yang menentukan sah atau tidaknya keterangan terdakwa sebagai alat bukti adalah bahwa keterangan itu harus diberikan di sidang pengadilan.

Dengan asas ini dapat disimpulkan, bahwa keterangan terdakwa yang dinyatakan di luar sidang pengadilan sama sekali tidak mempunyai nilai sebagai alat bukti sah. Walaupun keterangan terdakwa yang dinyatakan di luar sidang pengadilan tidak dapat dijadikan sebagai alat bukti, namun menurut ketentuan Pasal 189 ayat (2) KUHAP, keterangan terdakwa yang diberikan di luar sidang dapat dipergunakan untuk "membantu" menemukan alat bukti di sidang pengadilan, dengan syarat keterangan di luar sidang didukung oleh suatu alat bukti yang sah, dan keterangan yang dinyatakan di luar sidang sepanjang mengenai hal yang didakwakan kepada terdakwa (Yahya Harahap, 2003).

Bentuk keterangan yang dapat dikualifikasi sebagai keterangan terdakwa yang diberikan di luar sidang ialah : a) keterangan yang diberikan dalam pemeriksaan penyidikan, b) keterangan itu itu dicatat dalam berita acara penyidikan, c) serta berita acara penyidikan itu ditandatangani oleh pejabat penyidik dan terdakwa.

g) Nilai Kekuatan Pembuktian Keterangan Terdakwa

Secara umum dapat dikatakan bahwa undang-undang tidak dapat menilai keterangan terdakwa sebagai alat bukti yang memiliki nilai pembuktian yang sempurna, mengikat, dan menentukan. Namun demikian, keterangan terdakwa tetap memiliki pengaruh terhadap proses persidangan. Adapun nilai kekuatan pembuktian alat bukti keterangan terdakwa dapat dirumuskan sebagai berikut:

a) Sifat nilai kekuatan pembuktiannya adalah bebas

b) Harus memenuhi batas minimum pembuktian

c) Harus memenuhi asas keyakinan hakim

\subsection{Penyangkalan Terdakwa Ditingkat Persidangan (di Pengadilan Negeri Makassar)}

Dalam pemeriksaan tersangka pada tingkat penyidikan oleh kepolisian masih terdapat penyalahgunaan kewenangan, khususnya dalam pembuatan Berita Acara Pemeriksaan (BAP) tersangka, oleh karena masih ada tersangka atau terdakwa pada saat persidangan yang mencabut atau menyangkali keterangan yang diberikan pada pemeriksaan ditingkat penyidikan oleh polisi atau dengan kata lain bahwa terdakwa menyangkali keterangannya di tingkat persidangan, dengan alasan, bahwa pada saat memberikan keterangan di hadapan penyidik, terdakwa dipaksa atau dipukul untuk mengakui tindak pidana yang didakwakan kepadanya. Berpijak pada ketentuan Pasal 189 ayat (1) KUHAP, pada prinsipnya keterangan terdakwa adalah apa yang diberikan terdakwa di sidang pengadilan. Meskipun demikian ketentuan itu ternyata tidak mutlak, karena keterangan terdakwa yang diberikan di luar sidang dapat pula digunakan untuk membantu menemukan bukti di persidangan asalkan keterangan itu didukung oleh suatu alat bukti yang sah sepanjang mengenai hal yang didakwakan kepadanya (Pasal 189 ayat (2) KUHAP). Hal ini dapat dimaklumi karena pada prinsipnya KUHAP menganut asas fair trial, dimana dalam asas ini terdakwa memiliki hak untuk memberikan keterangan secara bebas (Pasal 153 ayat (2) huruf b KUHAP), termasuk hak untuk menarik keterangannya di sidang pengadilan. Namun satu hal yang perlu diingat, KUHAP hanya memberikan jaminan kebebasan untuk memberikan keterangan, bukan kebebasan untuk menyampaikan kebohongan.

Dalam penulisan ini penulis mengambil kasus terjadinya penyangkalan terdakwa yang terjadi di pengadilan Negeri Makassar dengan Putusan Nomor: 179/Pid.Sus/2017/ PN. Mks tanggal 11 April 2017, dalam perkara tindak pidana "pencurian dengan kekerasan yang dilakukan di jalan umum, yang dilakukan oleh dua orang atau lebih dengan bersekutu” sebagaimana diatur dan diancam pidana dalam pasal 365 ayat (2) ke-1 dan 2 KUHP.

Berdasarkan hasil pemeriksaan di persidangan, diketahui bahwa benar telah terjadi Penyangkalan terdakwa, dimana terdakwa dalam keterangannya dipersidangan, menarik seluruh keterangan pengakuan yang diberikannya pada tingkat pemeriksaan penyidikan di kepolisian. Dengan alasan bahwa pada waktu dilakukan pemeriksaan di depan Penyidik, terdakwa dipaksa untuk mengaku dan dipukul sehingga merasa tersiksa baik fisik maupun psikisnya.

Adapun fakta-fakta yang menandakan telah terjadinya Penyangkalan terdakwa dalam persidangan:

a) Fakta dari hasil pemeriksaan alat bukti keterangan terdakwa dalam persidangan disesuaikan dengan pengakuan terdakwa dalam BAP.

Berikut beberapa hasil pemeriksaan di pengadilan Negeri Makassar terhadap terdakwa yang menunjukan adanya penyangkalan atas isi BAP berdasarkan pertanyaan hakim 
dalam persidangan:

1) Bahwa terdakwa sebelumnya pernah diperiksa di kepolisian

2) Bahwa semua keterangan yang terdakwa berikan waktu itu tidak benar karena pada saat diperiksa terdakwa dipukul

3) Bahwa masalah yang terdakwa ketahui sehingga terdakwa diajukan kepersidangan ialah mengenai masalah pencurian

4) Bahwa terdakwa hanya melakukan jambret pada hari sabtu tanggal 26 November 2016, sekira pukul 22.00 Wita di Jl.Andalas Makassar, sedangkan barang yang terdakwa ambil waktu itu adalah HP dan pencurian dengan laptop di Jl. Ws. Husodo, terdakwa tidak pernah melakukan

5) Bahwa dalam Berita Acara Pemeriksaan (BAP) yang terdakwa akui semua pada saat dipolisi ialah terpaksa mengakui karena disiksa dipukul lalu terdakwa menanda tangani berita acara tersebut karena sudah tidak tahan dipukul

6) Bahwa terdakwa masih ingat siapa yang memukul terdakwa waktu itu yang itu terdakwa dipukul oleh polisi yang melakukan pemeriksaan pada tingkat penyidikan

7) Bahwa terdakwa kenal dengan saksi Irwan alias Cambang bin Abd Salam (terdakwa dalam perkara terpisah) baru sekitar 1 (satu) bulan di jl. Laiya Makassar

8) Bahwa terdakwa tidak kenal dengan orang yang bernama $A c o$, nama itu hanya asal disebut saja oleh saksi Irwan alias Cambang Bin Abd. Salam (terdakwa dalam perkara terpisah) karena dipaksa

9) Bahwa yang lebih dulu ditangkap adalah saksi Irwan alias Cambang Bin Abd. Salam (terdakwa dalam perkara terpisah), lalu sekitar 1 (satu) jam kemudian baru terdakwa ditangkap

10) Bahwa pada saat kejadian terdakwa berada dirumah terdakwa bersama dengan orang tua terdakwa dan tetangga

11) Bahwa terdakwa diperlihatkan CCTV pada saat diperiksa tetapi hanya sekilas saja dan itu tidak jelas

12) Bahwa sebelum terdakwa menandatangani Berita Acara pemeriksaan diperlihatkan kepada terdakwa

13) Bahwa terdakwa dipukul pada saat sebelum dan sesudah diperiksa dan Berita Acara Pemeriksaan (BAP) terdakwa yang ditanda tangani itu bukan keterangan terdakwa tetapi hanya cerita dari saksi Irwan alias Cambang Bin Abd. Salam (terdakwa dalam perkara terpisah)

14) Bahwa pada saat terdakwa diperiksa di Kejaksaan tidak membantah karena terdakwa takut dikarenakan polisi waktu itu ikut

15) Bahwa pada saat terdakwa dilakukan pemeriksaan oleh polisi saat itu bersama dengan saksi Irwan alias Cambang Bin Abd. Salam (terdakwa dalam perkara terpisah) dan berkas langsung digabung

16) Bahwa awalnya terdakwa diperiksa sehubungan dengan masalah Jambret di Jl. Andalas Makassar, kemudian terdakwa dipaksa juga oleh polisi untuk mengakui pencurian Laptop di Jl. WS. Husodo Makassar

Dari uraian di atas, diketahui bahwa terdakwa telah menyangkal semua isi BAP atau mengingkari semua pengakuan yang diberikannya di tingkat pemeriksaan penyidikan, selain itu terdakwa juga memberikan keterangan baru yang tidak diutarakan di depan penyidik. Maka dengan adanya penyangkalan atau pengingkaran tersebut, maka terbukti bahwa terdakwa benar-benar telah mencabut keterangannya di sidang pengadilan.

b) Fakta yang termuat dalam surat penuntutan.

Dalam petikan surat tuntutan juga terdapat keterangan yang menunjukan adanya Penyangkalan terdakwa dalam persidangan, antara lain sebagai berikut:

"Keterangan terdakwa yang tidak mengakui Berita Acara Pemeriksaan dari Penyidik dan tidak mengakui perbuatannya dan memberikan keterangan yang berbelitbelit, juga mencabut semua keterangan yang diberikannya waktu penyidikan, adalah tanpa alasan yang mendasar".

Dari petikan surat tuntutan di atas, dapat disimpulkan bahwa pada prinsipnya Penuntut Umum juga menilai telah terjadi Penyangkalan terdakwa di persidangan. Penilaian penuntut umum ini semakin memperjelas, bahwa terdakwa, memang telah mencabut keterangannya di sidang pengadilan.

c) Fakta yang termuat dalam pledoi atau pembelaan dari penasehat hukum terdakwa.

Dalam persidangan terdakwa, didampingi penasehat hukum bernama H. Syamsuddin Sampara, SH., M.Hum, Muh. Fajrin, Sh dan Syaiful Syahrir,SH. Kesemuanya advokat / Penasehat hukum pada kantor Advokat / Penasehat hukum " Kelara Keadilan " yang beralamat di jalan Sungai Kelara No.28 Makassar, berdasarkan Surat Kuasa Khusus tertanggal 4 Februari 2017 dan telah terdaftar di Kepaniteraan Pengadilan Negeri tertanggal 7 Februari 2017 Nomor:78/Pid/2017/UB.

Dalam isi pembelaan dari penasihat hukum terdakwa, yang pada pokoknya menyatakan bahwa unsur-unsur dari dakwaan Jaksa Penuntut Umum tidak terpenuhi karena terdakwa tidak melakukan perbuatan tindak pidana sebagaimana dimaksud dalam dakwaan Jaksa Penuntut Umum, sedangkan keterangan dari terdakwa dalam Berita Acara pemeriksaan (BAP) terdakwa bukanlah keterangan dari terdakwa melainkan keterangan yang dikarang oleh saksi Irwan Alias Cambang Bin Abd. Salam (terdakwa dalam perkara terpisah), dan terdakwa menandatangani Berita Acara Pemeriksaan (BAP) tersebut karena dipaksa dan dipukul oleh penyidik.

\section{d) Fakta yang tertuang dalam petikan putusan pidana}

Dalam petikan putusan pengadilan Nomor:179/Pid.Sus/2017/ PN.Mks, tanggal 11 April 2017, terutama pada bagian pertimbangan-pertimbangan Majelis Hakim terhadap keterangan terdakwa, juga terdapat penjelasan yang menandakan adanya Penyangkalan terdakwa di persidangan. Berikut petikannya:

1) Bahwa pada intinya terdakwa dalam keterangannya di muka persidangan menyangkal semua dakwaan Penuntut Umum.

2) Bahwa di muka persidangan terdakwa menarik seluruh keterangannya yang tertuang di Berita Acara yang di buat Penyidik, dengan alasan bahwa pada waktu diperiksa di depan Penyidik terdakwa dipaksa dan dipukul untuk mengaku di depan Penyidik.

Berdasarkan fakta-fakta di atas, diketahui dan terbukti bahwa terdakwa dalam persidangan benar-benar telah menyangkali keterangan pengakuan yang diberikannya di tingkat pemeriksaan penyidikan. 
Suatu hal yang ironi dalam masalah ini jika terdakwa menyangkali keterangan pengakuan yang diberikan dalam pemeriksaan penyidikan di sidang pengadilan. Kalau dipukul rata hampir setiap keterangan pengakuan yang diberikan dalam pemeriksaan penyidikan, selalu dicabut kembali disidang pengadilan. Terdapat kecenderungan umum setiap tersangka akan memberikan keterangan pengakuan dalam pemeriksaan penyidikan. Jarang tersangka yang menyangkal kesalahan yang disangkakan dalam persidangan, semua berjalan dengan lancar mengakui kesalahan yang disangkakan sehingga pada umumnya Berita Acara penyidikan sedemikian rupa jelasnya mengutarakan dan menggambarkan jalannya perbuatan tindak pidana yang disangkakan.

Terlepas dari semua itu, bagaimana hukumnya penyangkalan keterangan terdakwa ditingkat persidangan, apakah undang-undang membenarkanpencabutan keterangan yang diberikan terdakwa diluar sidang tersebut. Ditinjau dari segi yuridis, terdakwa "berhak" dan dibenarkan "mencabut kembali" keterangan dan pengakuan yang diberikan dalam penyidikan. Undang-undang pun pada dasarnya tidak membatasi hak terdakwa untuk mencabut kembali keterangan yang demikian, asalkan pencabutan dilakukan selama pemeriksaan persidangan pengadilan berlangsung dan pencabutan itu mempunyai landasan alasan yang berdasar dan logis (M. Yahya Harahap, 2003).

Menilai alasan penyangkalan keterangan pengakuan, memerlukan kearifan dan ketelitian. Sehingga dalam mepertimbangkan alasan penyangkalan keterangan pengakuan, dari hakim dituntut kemampuan kecakapan hukum dan keterampilan penguasaan yang matang akan seluk beluk pembuktian dan penilaian kekuatan pembuktian yang diatur dalam hukum acara pidana serta dipadu dengan "intuisi dan seni mengadili“ . Jika ini semua dimiliki oleh hakim, dia mampu menilai dan mempertimbangkan alasan pencabutan dengan mantap dan utuh.

Penyangkalan kembali tanpa dasar yang logis adalah pencabutan yang tidak dapat dibenarkan oleh hukum, sebagaimana ditegaskan oleh beberapa Yurisprudensi, yang dijadikan pedoman dalam praktek peradilan sampai sekarang. Hal ini dapat dilihat dari putusan Mahkamah Agung tanggal 23 Februari 1960, No. 299 K/Kr/1959, yang menjelaskan: "pengakuan terdakwa di luar sidang yang kemudian di sidang pengadilan dicabut tanpa alasan yang berdasar merupakan petunjuk tentang kesalahan terdakwa".

Dari putusan ini dapat dilihat, antara lain:

1) Penyangkalan pengakuan yang dibenarkan hukum adalah pencabutan yang dilandasi dengan alasan yang berdasar dan logis,

2) Pencabutan tanpa dasar alasan, tidak dapat diterima,

3) Penolakan penyangkalan pengakuan, mengakibatkan pengakuan tetap dapat dipergunakan sebagai pembantu menemukan alat bukti.

Yurisprudensi yang senada dengan putusan di atas, antara lain putusan Mahkamah Agung tanggal 25 Februari 1960, No. $225 \mathrm{~K} / \mathrm{Kr} / 1960$, tanggal 25 Juni 1961, No. 6 K/Kr/1961 dan tanggal 27 September 1961, No. 5 K/Kr/196, yang menegaskan: "pengakuan yang diberikan di luar sidang tidak dapat dicabut kembali tanpa dasar alasan” (M. Yahya Harahap, 2003).

Dalam petikan putusan pengadilan Nomor: 179 / Pid.Sus / 2017 / PN. Mks, tanggal 11 April 2017 pada uraian di atas disebutkan bahwa terdakwa dalam persidangan pengadilan mencabut semua keterangan pengakuan yang di berikannya didepan penyidik dengan alasan bahwa pada saat diperiksa di depan Penyidik, terdakwa dipukul dan dipaksa untuk mengakui perbuatan tersebut, sehingga merasa tersiksa baik fisik maupun psikisnya maka terdakwa mengakui perbuatan yang disangkakan oleh penyidik. Akan tetapi, pada akhirnya yaitu saat pembacaan putusan, hakim menolak pencabutan tersebut.

Dengan adanya fakta - fakta hukum tersebut selanjutnya Hakim Majelis akan mempertimbangkan apakah terdakwa dapat dinyatakan bersalah serta dapat dijatuhi hukuman atas dakwaan yang didakwakan oleh Penuntut Umum kepada terdakwa dan terdakwa diajukan kemuka persidangan ini karena didakwa dengan dakwaan yang disusun dalam bentuk Dakwaan Tunggal, yaitu perbuatan terdakwa sebagaimana diatur dan diancam pidana dalam pasal 365 ayat (2) ke-1,dan 2 KUHP, dan oleh karenanya penyangkalan terdakwa terhadap Berita Acara Pemeriksaan (BAP) dari penyidik tidak beralasan dan mengada-ada, maka haruslah ditolak.

Maka berdasarkan hal - hal tersebut diatas Hakim Majelis akan mempertimbangkan pidana yang akan dijatuhkan kepada terdakwa yang dipandang cukup adil dan sepadan dengan kesalahan terdakwa sebagaimana dalam amar putusan sebagai berikut:

1) Menyatakan terdakwa telah terbukti secara sah dan meyakinkan bersalah melakukan tindak pidana "pencurian dengan kekerasan dalam keadaan memberatkan"

2) Menghukum terdakwa oleh karena itu dengan pidana penjara selama 2 (dua) tahun;

3) Menetapkan masa penahanan yang telah dijalani terdakwa dikurangkan seluruhnya dari pidana yang dijatuhkan;

4) Memerintahkan terdakwa tetap berada dalam tahanan

5) Menetapkan barang bukti berupa 1 (satu) unit sepeda motor Yamaha Mio GT warna putih DD 4558 XO, dikembalikan kepada terdakwa;

6) Membebankan kepada terdakwa untuk membayar biaya perkara sebesar Rp. 5.000,- (lima ribu rupiah).

Dari petikan putusan pengadilan nomor : 179 / Pid.Sus / 2017 /Pn.Mks, tanggal 11 April 2017 di atas diketahui pula bahwa setidaknya ada dua unsur penting yang dijadikan alasan atau pertimbangan oleh hakim dalam menolak Penyangkalan pengakuan terdakwa, yaitu: 1) unsur keterangan saksi verbalisan, dan 2) unsur pencabutan tanpa dasar dan logis, tidak dapat diterima

Berdasarkan seluruh uraian di atas dan hasil wawancara dengan Dodi Hendraskati, Hakim Pengadilan Negeri Makassar (pada tanggal 21 November 2019), bahwa pada prinsipnya penyangkalan keterangan terdakwa ditingkat persidangan boleh dilakukan oleh terdakwa, dengan syarat pencabutan dilakukan selama pemeriksaan persidangan pengadilan berlangsung dan disertai dengan alasan yang mendasar dan logis.

\subsection{Implikasi Penyangkalan Terdakwa Dalam Hubungannya Dengan Hukum Pembuktian}

Terlepas dari diterima atau tidaknya pencabutan keterangan terdakwa oleh hakim, dengan adanya pencabutan tersebut pasti akan mempengaruhi proses persidangan di pengadilan. Oleh karena itu perlu kesiapan dari hakim dan 
jaksa, terutama dalam hal penguasaan seluk-beluk pembuktian dan "seni mengadili".

Jika Penyangkalan keterangan terdakwa diterima oleh hakim mengakibatkan terdakwa bebas murni "vrijspraak" atas apa yang didakwakan (tuntutan) kepadanya dalam surat dakwaan, dan bila penyangkalan terdakwa ditolak oleh hakim, karena dinilai alasan pencabutan keterangan tidak berdasar dan tidak logis, maka penolakan tersebut ikut membawa dampak bagi kekuatan alat bukti keterangan terdakwa itu sendiri, yaitu dengan ditolaknya penyangkalan terdakwa ditingkat persidangan, maka Hakim menilai bahwa keterangan terdakwa (tersangka) di depan penyidiklah yang mengandung unsur kebenaran dan mempunyai nilai pembuktian, sedangkan keterangan terdakwa di persidangan yang menyangkal semua isi Berita Acara Pemeriksaan (BAP) dinilai tidak benar dan tidak ada nilainya sama sekali dalam pembuktian.

Atas penilaian ini, Hakim kemudian menganggap keterangan terdakwa (tersangka) di depan penyidik (BAP) dapat digunakan sebagai petunjuk untuk membuktikan kesalahan terdakwa. Karena pada dasarnya dengan ditolaknya penyangkalan tersebut berarti pengakuanpengakuan terdakwa yang tertulis dalam BAP diterima sebagai suatu kebenaran yang sangat membantu hakim dalam membuktikan kesalahan terdakwa. (Wawancara dengan Dodi Indraskti, Hakim Pengadilan Negeri Makassar pada tanggal 21 November 2019).

Penggunaan keterangan pengakuan terdakwa sebagai petunjuk ini dipertegas dengan Putusan Mahkamah Agung tanggal 20 September 1977 No.177.K/ Kr/1965, yang menegaskan: "Bahwa pengakuan-pengakuan terdakwa didepan penyidik dan Jaksa Penuntut Umum, ditinjau dalam hubungannya satu sama lain, dapat dipergunakan sebagai petunjuk untuk menetapkan kesalahan terdakwa”. Isi putusan Mahkamah Agung ini mengandung kaidah bahwa keterangan pengakuan yang diberikan di luar sidang, dapat dipergunakan hakim sebagai "petunjuk" untuk menetapkan kesalahan terdakwa.

Oleh karena itu dengan adanya penyangkalan keterangan terdakwa ditingkat persidangan yang tidak membenarkan keterangan terdakwa sewaktu diperiksa oleh penyidik sebagaimana yang tertuang dalam BAP, maka oleh hakim kemudian dijadikan petunjuk dalam menetapkan kesalahan terdakwa. Dengan pertimbangan hakim menggunakan keterangan dalam BAP sebagai petunjuk, adalah karena keterangan tersebut secara utuh menggambarkan kejadian peristiwa pidana yang didakwakan.

Keutuhan ini mampu melengkapi dan menegaskan alat bukti yang ditemukan dalam persidangan pengadilan. Dengan kata lain, kedudukan keterangan pengakuan yang diberikan terdakwa di depan pemeriksaan penyidikan, tidak bisa berdiri sendiri. Fungsinya hanya dapat dipergunakan sebagai petunjuk untuk menyempurnakan pembuktian alat bukti lain. Atau berfungsi dan bernilai "untuk mencukupi dan "mengungkapkan" keterbuktian kesalahan terdakwa.

Demikian halnya dengan kasus terdakwa dalam putusan pengadilan Negeri Makassar Nomor: 179/Pid.Sus/ 2017/PN. Mks, tanggal 11 April 2017, dalam perkara pencurian dengan kekerasan sebagaimana diatur dan diancam pidana dalam pasal 365 ayat (2) ke-1,dan $2 \mathrm{KUHP}$, dalam hal ini penyangkalan keterangan yang dilakukan terdakwa, ditolak oleh Hakim dengan dasar bahwa alasan pencabutan tersebut tidak terbukti kebenarannya, karena setelah dilakukan cross check dengan saksi verbalisan dan setelah Hakim melakukan pengamatan atas fakta-fakta dan alat-alat bukti dalam persidangan ternyata tidak satu pun yang dapat membenarkan alasan pencabutan keterangan pengakuan tersebut,maka keadaan ini dapat dijadikan petunjuk bagi hakim dalam menilai atau membuktikan kesalahan terdakwa.

Oleh karena itu implikasi dari ditolaknya penyangkalan keterangan terdakwa adalah, hakim akan menilai keterangan terdakwa di sidang pengadilan sebagai suatu keterangan yang tidak mengandung unsur kebenaran dan tidak ada nilainya sama sekali dalam pembuktian (tidak dapat digunakan sebagai alat bukti) dan implikasi dari ditolaknya penyangkalan terdakwa tersebut diatas, maka konsekuensi yuridisnya adalah keterangan terdakwa dalam persidangan pengadilan tidak dapat digunakan sebagai alat bukti, justru keterangan terdakwa (tersangka), di tingkat penyidikanlah (BAP) yang kemudian dapat digunakan dalam membantu menemukan bukti di persidangan, sehingga dengan itu bahwa adanya penyangkalan terdakwa di tingkat persidangan tidak dapat mematahkan tuntutan dan tidak dapat mempengaruhi putusan hakim dalam menjatuhkan putusan kepada terdakwa.

\section{KESIMPULAN}

Hasil penelitian dan pembahasan menujukkan bahwa prinsipnya keterangan terdakwa adalah apa yang diberikan terdakwa di sidang pengadilan, oleh karena pada prinsipnya KUHAP menganut asas fair trial, dimana dalam asas ini terdakwa memiliki hak untuk memberikan keterangan secara bebas (Pasal 153 ayat (2) huruf b KUHAP), termasuk hak untuk menarik keterangannya di sidang pengadilan sehingga penyangkalan terdakwa dalam persidangan boleh dilakukan oleh terdakwa, dengan syarat pencabutan dilakukan selama pemeriksaan persidangan pengadilan berlangsung dan disertai dengan alasan yang mendasar dan logis

\section{DAFTAR PUSTAKA}

Adnan Paslyadja. 2009. Hukum Pembuktian. Jakarta: Pusat Diktat Kejaksaan Republik Indonesia.

Andi Hamzah. 2002. Hukum Acara Pidana Indonesia. Jakarta: Sinar Grafika.

Darwan Prinst. 2002. Hukum Acara Pidana Dalam Praktik. Jakarta: Djambatan.

Eddy O.S. Hiariej. 2012. Teori dan hukum pembuktian, Erlangga

Hari Sasangka dan Lily Rosita2003Hukum Pembuktian Dalam Perkara Pidana.Bandung:Mandar Maju

M. Yahya Harahap. 2003. Pemerikasaan Sidang Pengadilan, Banding, Kasasi, dan Peninjauan Kembali: Edisi Kedua. Jakarta: Sinar Grafika.

Martiman Prodjohamidjojo. 2003. Komentar Atas KUHAP: Kitab Undang-Undang Hukum Acara Pidana. Jakarta: Pradnya Paramita.

Munir Fuady. 2006. Teori hukum pembuktian (Pidana dan perdata), Bandung PT Citra aditya Bakti

Peraturan pemerintah No. 58 tahun 2010 tentang perubahan atas Peraturan pemerintah nomor 27 tahun 1983 tentang pelaksanaan Kitab Undang-Undang Hukum Acara Pidana (KUHAP) 
Ruslan Renggong.2014 Hukum Acara Pidana, Jakarta Prenadamedia group

Satjipto Rahardjo. 1982. Ilmu Hukum. Bandung: Alumni.

Sinar Grafika. 2000. KUHAP dan KUHP. Jakarta: Sinar Grafika.

Soerjono, Soekanto, 2009. Penelitian Hukum Normatif. Jakarta PT. Raja Grafindo Persada.

Subekti. 2001. Hukum Pembuktian. Jakarta: Pradnya Paramita.

Undang - undang No. 12 tahun 1995 tentang pemasyarakatan

Undang - undang No. 16 tahun 2004 tentang Kejaksaan Republik Indonesia

Undang - undang No. 18 tahun 2003 tentang Advokat

Undang - undang No. 2 tahun 2002 tentang Kepolisian Negara Republik Indonesia

Undang - undang No. 48 tahun 2009 tentang kekuasaan kehakiman

Undang - Undang No. 8 tahun 1981 tentang Kuhap 